\title{
The Development of a Student Teachers Teaching Demonstration Performance Evaluation Tool
}

\author{
Jeromil O. Enoc (MA. Ed) \\ College of Teacher Education, Cebu Normal University, \\ Osmeña Blvd., Cebu City, Philippines
}

Doi:10.19044/esj.2019.v15n16p75 ～URL:http://dx.doi.org/10.19044/esj.2019.v15n16p75

\begin{abstract}
This paper focuses on developing a tool that measures the teaching demonstration performance of student teachers. To achieve this, constructs or factors that affect their teaching performance have to be determined first as these will be used as indicators in measuring the performance. Semi-structured interviews conducted among ten purposively selected student teachers and five cooperating teachers produced eighteen thematic statements as indicators in measuring teaching demonstration performance. These were added to fiftyfive indicators synthesized from the different literature reviews, producing a total of seventy-three indicators. After content and expert validation, these indicators were further deliberated and refined, producing only thirty-two which were used in a 5-point Likert scale questionnaire administered to twohundred and sixty-five cooperating teachers. Through principal component extraction, six constructs or factors with eigenvalues greater than one were extracted which were named as follows: classroom management, teaching strategy, lesson planning, professional behavior, accuracy and fluency of communication, and voice modulation. The variance explained by each of these factors became the basis in giving its weight in the proposed tool that would measure the teaching demonstration performance of student teachers.
\end{abstract}

Keywords: Teaching demonstration performance, tool development, student teachers, principal component analysis

\section{Introduction}

While there are already a lot of studies conducted on pre-service or student teachers during their student teaching internship (such as Walker, 2014; Morris, 2007; Lockwood, 2001; Alvis, 2009; Hrncir, 2007, Wang, 2010; Cruz, 2002; Cil, 2014; Patton, 2002; Koc, 2011; Perry, 2016; Winters, 2010; Nordyke, 2011; Boyac et al., 2016; Caster, 2018; Al Barwani et al., 2012; Meng \& Muñoz, 2016; Schilling,1997; Anwer et al., 2017; Williams, 2010; 
Taylor, 2010; Gholam \& Kobeissi, 2012), little has been known about measuring their performance in a single teaching demonstration. A teaching demonstration or a lesson demonstration as operationally defined in this study is a planned lesson taught to a group of K-12 students for just a single period which could span around 50 to 90 minutes. Hence, this study aims to develop an instrument that is specifically designed to measure teaching performance for a single teaching demonstration. So far, after intensive literature reviews, the researchers have not found instruments that could appropriately be used for the mentioned purpose.

There are already a few existing tools used to measure pre-service teachers' teaching performance (Audet, 2014; Ingle, 2017; Aktag, 2003; Miller, 2001; Yu, 2013; Alrefaei, 2015; Hatcher, 2008; Perkmen, 2008; Rachal, 1981). However, they seem insufficient and not very relevant to answer this identified need. The basic reason for this need is that these current instruments include teaching competencies, which can hardly be observed in a single lesson demonstration and are therefore hard to measure. Examples include community relationships and other personality traits of a student teacher/pre-service teacher. These characteristics are not readily manifested or observable in a single lesson demonstration. Hence, more time is needed to truly measure them. Another problem is that many current instruments give the items or indicators to be equal to weight, asking the rater to sum up the scores or values and get their average. This rating system can be considered very deficient and has to be improved. This is because there are apparently factors which are deemed more important than the others that have a significant effect on the success of a teaching demonstration.

Hence, based on the above-mentioned problem, this study aims to: (a) identify the factors or teaching performance indicators that are very relevant and applicable in a single teaching demonstration, (b) determine which of these factors has the greatest effect on teaching demonstration performance, and (c) utilize these indicators for the development of an instrument designed to measure the teaching demonstration performance of pre-service teachers.

\section{Methodology}

This paper follows DeVellis' (2017) eight-step process in developing a tool or scale. The process has been widely accepted in the literature as having a rigorous methodology for developing a scale. The eight-step process includes: (a) determine clearly what it is you want to measure, (b) generate an item pool, (c) determine the format for measurement, (d) have an initial item pool reviewed by experts, (e) consider inclusion of validation items, (f) administer items to a development sample, (g) evaluate the items, and (h) optimize the scale length. 


\section{Determine Clearly What it is You Want to Measure}

This study aims to develop a tool that measures the teaching demonstration performance of student teachers. To achieve this goal, factors that affect the demonstration performance of student teachers have to be determined first. DeVellis (2017) discussed in this step the importance of the distinctiveness of the construct to be measured as this allows for clarity and specificity in the development of the tool. Hence, while the results of the different literature reviews revealed many tools to measure teaching performance, this study focuses on developing indicators that will specifically measure student teachers' teaching demonstration performance in a one-time setting.

\section{Generate an Item Pool}

To be able to generate the items, a semi-structured interview was conducted among five cooperating teachers and ten student teachers who are purposively selected in one public laboratory school in Cebu City, Philippines. The sample was relatively small, but it allowed an abundance of information from the participants who were asked the following related questions: What do you think are the teaching performance indicators that are very much measurable in a single teaching demonstration? Which of these factors or indicators has the greatest effect on teaching demonstration performance?

By clustering the thematic and recurrent ideas and statements from the interview, eighteen (18) indicators, which the participants believe are very much observable and measurable in a single teaching demonstration of a student teacher, were formulated. Table 1 shows the list in no particular order (see Table 1).

\section{Table 1. Thematic Statements on Indicators of an Effective Teaching Demonstration}

- Utilizes motivational activity that effectively connects or introduces the lesson

- Manifests professional confidence and authority in class

- Provides opportunities for follow up or application of the lesson

- Employs a variety of teaching techniques and strategies

- Provides closure, recap or a summarizing activity

- Observes or follows the principles of test construction \& administration

- Maintains order and discipline

- Exhibits orderliness or being organized in conducting class activities

- Reminds the students of some rules/routines to follow

- Exhibits mastery of the subject matter

- Utilizes appropriate and well-designed instructional materials

- Exhibits efficient time management skills

- Uses the required medium of instruction

- Have a clear, pleasant, \& non-irritating voice

Have a well-modulated voice, loud enough for the class to hear

- Exhibits effective communication with fluency and accuracy

- Submits the lesson plan early enough for checking and approval

- Develops measurable cognitive, affective, and psychomotor learning objectives 
In addition to the indicators formulated based on the interviews, more indicators were added based on the literature reviews conducted. The following are the different literature authors and the corresponding number of indicators deemed relevant by each, hence included in the current study (Refer to Appendix A for the detailed list of indicators).
A. Al Barwani, et al. (2012)
-9 indicators
B. Meng, L. \& Muñoz, M. (2016)
-11 indicators
C. Schilling, J. W. (1997)
-8 indicators
D. Anwer, et al. (2017)
-6 indicators
E. Williams, R. E. (2010)
-12 indicators
F. Taylor, K. R. (2010)
-3 indicators
G. Gholam, A. P. \& Kobeissi, A. H. (2012)
-5 indicators

Of these, fifty-four (54) in all were added to the eighteen (18) indicators shared in Table 1, totaling a new list of seventy-two (72).

\section{Determine the Format for Measurement}

As described by DeVellis (2017), tools consisting of items or indicators that can be scored on a continuum are very compatible with a theoretical orientation like the one in this study. In this study, through a 5point Likert scaled questionnaire, the respondents were asked to rate the indicators' importance from not important (1) to very important (5).

\section{Initial Pool Review}

The eighteen statements in Table 1 and the fifty-four from the literature review were further deliberated and synthesized through content validation by three cooperating teachers. As advised by DeVellis (2017), experts reviewed the appropriateness and relevance of the items for the specified construct to be measured. The clarity of the items and their conciseness was also evaluated.

\section{Consider the Inclusion of Validation Items}

The initial validation process reduced the indicators to thirty-two from the original seventy-two. Table 2 shows the synthesized thirty-two indicators for measuring the effectiveness of a single teaching demonstration of a preservice student teacher (see Table 2).

Table 2. Thirty-two Indicators for Measuring the Effectiveness of a Teaching Demonstration

1. Utilizes motivational activity that effectively connects or introduces the lesson

2. Utilizes higher-order-thinking questions

3. Taps or activating the prior knowledge of students

4. Provides opportunities for follow up or application of the lesson

5. Utilizes appropriate and well-designed instructional materials

6. Provides variety of activities for students' active participation

7. Relates the lesson to students' real-life situations 
8. Uses effective grouping and cooperative learning strategies

9. Employs a variety of teaching techniques and strategies

10. Provides closure, recap or a summarizing activity

11. Designs assessment/testing procedures that are aligned with the stated objectives

12. Utilizes higher order thinking questions in Test/Assessment tasks

13. Observes or follows the principles of test construction \& administration

14. Maintains order and discipline

15. Sets the mood or atmosphere of the class for the lesson

16. Exhibits orderliness or being organized in conducting class activities

17. Reminds the students of some rules/routines to follow

18. Utilizes strategies to reinforce positive behavior and prevent the negative ones

19. Exhibits efficient time management skills

20. Limits interruptions and focusing classroom time on teaching and learning

21. Uses the required medium of instruction

22. Have a clear, pleasant, \& non-irritating voice

23. Have a well-modulated voice, loud enough for the class to hear

24. Exhibits effective communication with fluency and accuracy

25. Manifests professional confidence and authority in class

26. Displays excitement and enthusiasm in teaching

27. Demonstrates control, poise, and patience towards the class

28. Exhibits mastery of the subject matter

29. Submits the lesson plan early enough for checking and approval

30. Develops measurable cognitive, affective

31. Designs lesson plan that exhibits accuracy in the use of language

32. Designs appropriate activities to achieve the stated objectives

\section{Administer Items to a Development Sample}

The questionnaire was administered to two hundred sixty-five cooperating teachers asking them to rate the indicators' importance from not important (1) to very important (5). The respondents were cooperating teachers in different public and private schools in Cebu, catering student teachers from various teacher-training institutions.

\section{Evaluate the Items}

The developed Likert-type questionnaire was pilot tested. This pilot is used to check the internal consistency of the items or how closely related they are in measuring the construct. The tool yielded an alpha value of 0.930, suggesting relatively high internal consistency (Cronbach, 1951). The authors then applied factor analysis and principal component analysis (PCA) (Pearson, 1901; Joliffe \& Morgan, 1992) in extracting independent factors to the data gathered. PCA is a kind of data reduction technique that by analyzing correlations between variables reduces the original number of variables into fewer factors, which explain much of the original data. To check the appropriateness of the data for principal component analysis, the authors used measures of sampling adequacy using Bartlett's (Bartlett, 1950; Taherdoost, 
Sahibuddin, \& Jalaliyoon, 2014) test of Sphericity and correlation between variables by Kaiser-Meyer-Olkin (KMO) (Kaiser, 1960; Yong \& Pearce, 2013) value. KMO calculates the extent of variability in the data, while the Bartlett Test of Sphericity determines whether the items are sufficiently correlated for factor analysis.

The KMO measure of the data is 0.905 , which is characterized as "marvelous" (Kaiser, 1970), and the Bartlett Test was significant at a probability less than 0.000 , thus providing evidence of sufficient interrelatedness among the items. These results supported the appropriateness of factor analysis for the analysis of gathered data. For extracting independent factors, the authors used principal component analysis and retained all the factors with eigenvalues greater than one (Bowman, 1984). Eigenvalue represents the total variance explained by each factor. Table 3 confirms that there are six factors having Eigenvalues more than 1. The scree plot shown below supports the extraction of the desired number of factors. For these extracted factors, the total variance explained is $66.117 \%$.

Table 3. Total Variance Explain

\begin{tabular}{|c|c|c|c|c|c|c|c|c|c|}
\hline \multirow[b]{2}{*}{ Component } & \multicolumn{3}{|c|}{ Initial Eigenvalues } & \multicolumn{3}{|c|}{$\begin{array}{c}\text { Extraction Sums of Squared } \\
\text { Loadings } \\
\end{array}$} & \multicolumn{3}{|c|}{$\begin{array}{c}\text { Rotation Sums of Squared } \\
\text { Loadings }\end{array}$} \\
\hline & Total & $\begin{array}{c}\% \text { of } \\
\text { Variance }\end{array}$ & $\begin{array}{c}\text { Cumulative } \\
\%\end{array}$ & Total & $\begin{array}{c}\% \text { of } \\
\text { Variance }\end{array}$ & $\begin{array}{c}\text { Cumulative } \\
\%\end{array}$ & Total & $\begin{array}{c}\% \text { of } \\
\text { Variance }\end{array}$ & $\begin{array}{c}\text { Cumulative } \\
\%\end{array}$ \\
\hline 1 & 12.661 & 39.565 & 39.565 & 12.661 & 39.565 & 39.565 & 5.056 & 15.801 & 15.801 \\
\hline 2 & 2.213 & 6.915 & 46.479 & 2.213 & 6.915 & 46.479 & 4.252 & 13.286 & 29.087 \\
\hline 3 & 1.949 & 6.089 & 52.569 & 1.949 & 6.089 & 52.569 & 3.509 & 10.967 & 40.054 \\
\hline 4 & 1.860 & 5.813 & 58.382 & 1.860 & 5.813 & 58.382 & 3.370 & 10.532 & 50.586 \\
\hline 5 & 1.354 & 4.231 & 62.612 & 1.354 & 4.231 & 62.612 & 2.982 & 9.318 & 59.904 \\
\hline 6 & 1.121 & 3.504 & 66.117 & 1.121 & 3.504 & 66.117 & 1.988 & 6.213 & 66.117 \\
\hline 7 & .987 & 3.085 & 69.202 & & & & & & \\
\hline 10 & .766 & 2.393 & 77.016 & & & & & & \\
\hline
\end{tabular}

Extraction Method: Principal Component Analysis.

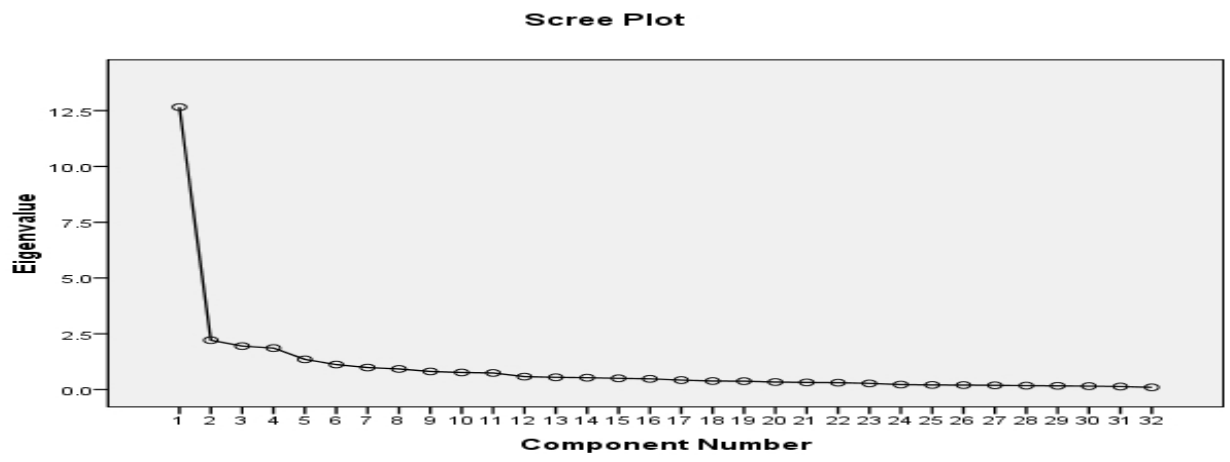


The results were obtained through orthogonal rotations with "varimax" and all the factor loadings greater than 0.4 were retained (see Table 4). An orthogonal rotation produces a loading matrix that displays the correlations between observed variables and factors (Popham, 1990).

With 6 factors or components extracted, component 4, 5, and 6 have 3 variables with factor loadings greater than 0.4 , while other components have at least 4 variables.

Table 4. Rotated Component Matrix ${ }^{\mathrm{a}}$

\begin{tabular}{|c|c|c|c|c|c|c|}
\hline & \multicolumn{6}{|c|}{ Component } \\
\hline & 1 & 2 & 3 & 4 & 5 & 6 \\
\hline VAR00001 & .308 & .415 & .518 & .039 & .221 & -.137 \\
\hline VAR00002 & .406 & .342 & .606 & .016 & -.039 & .085 \\
\hline VAR00003 & .475 & .502 & .279 & -.074 & .149 & .402 \\
\hline VAR00004 & .250 & .684 & .247 & .151 & .075 & .204 \\
\hline VAR00005 & .266 & .449 & .237 & .326 & .340 & -.009 \\
\hline VAR00006 & -.060 & .569 & .288 & .535 & .163 & .005 \\
\hline VAR00007 & .005 & .736 & .037 & .085 & -.057 & .171 \\
\hline VAR00008 & .276 & .730 & .109 & .067 & .021 & .079 \\
\hline VAR00009 & .148 & .590 & .169 & .320 & .260 & -.062 \\
\hline VAR00010 & .368 & .564 & .141 & .101 & .397 & .239 \\
\hline VAR00011 & .535 & .295 & .367 & .180 & .296 & -.074 \\
\hline VAR00012 & .551 & .367 & .458 & .033 & .169 & .047 \\
\hline VAR00013 & .515 & .327 & .122 & -.032 & .456 & .117 \\
\hline VAR00014 & .732 & .008 & .076 & .100 & .075 & .197 \\
\hline VAR00015 & .788 & .259 & -.035 & .085 & .036 & .029 \\
\hline VAR00016 & .738 & .159 & .208 & .359 & .136 & .102 \\
\hline VAR00017 & .481 & .405 & .126 & .185 & .278 & .152 \\
\hline VAR00018 & .568 & .225 & .057 & .441 & .439 & -.030 \\
\hline VAR00019 & .533 & .096 & .238 & .549 & .196 & .094 \\
\hline VAR00020 & .464 & .101 & .153 & .231 & .263 & .282 \\
\hline VAR00021 & .176 & .103 & .197 & .056 & .783 & .147 \\
\hline VAR00022 & .285 & .271 & -.018 & .169 & .324 & .651 \\
\hline VAR00023 & .067 & .219 & .120 & .326 & .133 & .626 \\
\hline VAR00024 & .265 & .062 & -.012 & .320 & 697 & .223 \\
\hline VAR00025 & .176 & .103 & -.025 & .830 & .109 & .201 \\
\hline VAR00026 & .072 & .153 & .304 & .584 & -.066 & .457 \\
\hline VAR00027 & .471 & -.067 & .396 & .285 & .148 & .494 \\
\hline VAR00028 & .352 & .197 & .004 & .666 & .048 & .166 \\
\hline VAR00029 & .018 & .127 & .579 & .487 & .245 & .113 \\
\hline VAR00030 & .061 & .303 & .783 & .043 & .051 & .061 \\
\hline VAR00031 & .023 & .039 & .477 & -.002 & 635 & .036 \\
\hline VAR00032 & .124 & -.022 & .740 & .153 & .279 & .229 \\
\hline \multicolumn{7}{|c|}{$\begin{array}{l}\text { Extraction Method: Principal Component Analysis. } \\
\text { Rotation Method: Varimax with Kaiser Normalization. }\end{array}$} \\
\hline
\end{tabular}


However, if other factor runs are done specifying only 5 factors, it would be observed that the 3 variables in component 5 and the 3 in component 6 are all loaded under the same factor. With this result, however, the researchers decided to have 6 factors, considering that the fifth and sixth factors, although very much related, are also very much distinguishable from each other. According to Gorsuch (1983), there is no single method or way in determining the number of factors to extract because it depends upon the purpose of the study and it is for the authors to decide and reflect on further.

\section{Results and Discussion}

For the naming of the factors extracted, the author identified the associated variables. Thus, Table 4 and Table 5 clearly depict that Factor 1 is a linear combination of variable number 14, 16, 15, 11, 12, 13, 17, 18, and 20. Factor 2 is a linear combination of variable number 8, 7, 3, 4, 5, 6, 9, and 10. Factor 3 is a linear combination of variable number 30, 32, 1, 29, and 2. Factor 4 is a linear combination of variable number 25,26 , and 28 . Factor 5 is a linear combination of variable number 21, 24, and 31. Finally, Factor 6 is a linear combination of variable number 22, 23, and 27.

Table 5. Naming of Factors/Dimension

\begin{tabular}{|c|c|c|c|c|}
\hline $\begin{array}{c}\text { Factor } \\
\text { No. }\end{array}$ & $\begin{array}{l}\text { Item } \\
\text { No. }\end{array}$ & $\begin{array}{c}\text { Factor } \\
\text { Loading }\end{array}$ & Item Description & $\begin{array}{c}\text { Name of } \\
\text { Dimension }\end{array}$ \\
\hline \multirow[t]{9}{*}{ F 1} & 14 & .788 & $\begin{array}{l}\text { Sets the mood or atmosphere of the class for } \\
\text { the lesson }\end{array}$ & \multirow{9}{*}{$\begin{array}{c}\text { Classroom } \\
\text { Management }\end{array}$} \\
\hline & 16 & .738 & $\begin{array}{l}\text { Exhibits orderliness /being organized in } \\
\text { conducting class activities }\end{array}$ & \\
\hline & 15 & .732 & Maintains order and discipline & \\
\hline & 11 & .568 & $\begin{array}{l}\text { Utilizes strategies to reinforce positive } \\
\text { behavior and prevent the negative ones }\end{array}$ & \\
\hline & 12 & .551 & $\begin{array}{c}\text { Utilizes higher order thinking questions in } \\
\text { Test/Assessment tasks }\end{array}$ & \\
\hline & 13 & .515 & $\begin{array}{c}\text { Observes the principles of test construction \& } \\
\text { administration }\end{array}$ & \\
\hline & 17 & .481 & $\begin{array}{l}\text { Reminds the students of some rules/routines } \\
\text { to follow }\end{array}$ & \\
\hline & 18 & .535 & $\begin{array}{l}\text { Designs assessment/testing procedures that } \\
\text { are aligned with the stated objectives }\end{array}$ & \\
\hline & 20 & .464 & $\begin{array}{c}\text { Limits interruptions \&focuses classroom time } \\
\text { on teachin\&learning }\end{array}$ & \\
\hline \multirow[t]{4}{*}{ F 2} & 8 & .730 & $\begin{array}{c}\text { Uses effective grouping and cooperative } \\
\text { learning strategies }\end{array}$ & \multirow{4}{*}{$\begin{array}{l}\text { Teaching } \\
\text { Strategy }\end{array}$} \\
\hline & 7 & .736 & $\begin{array}{c}\text { Relates the lesson to students' real-life } \\
\text { situations }\end{array}$ & \\
\hline & 3 & .502 & $\begin{array}{c}\text { Taps or activates the prior knowledge of } \\
\text { students }\end{array}$ & \\
\hline & 4 & .684 & $\begin{array}{l}\text { Provides opportunities for follow up or } \\
\text { application of the lesson }\end{array}$ & \\
\hline
\end{tabular}




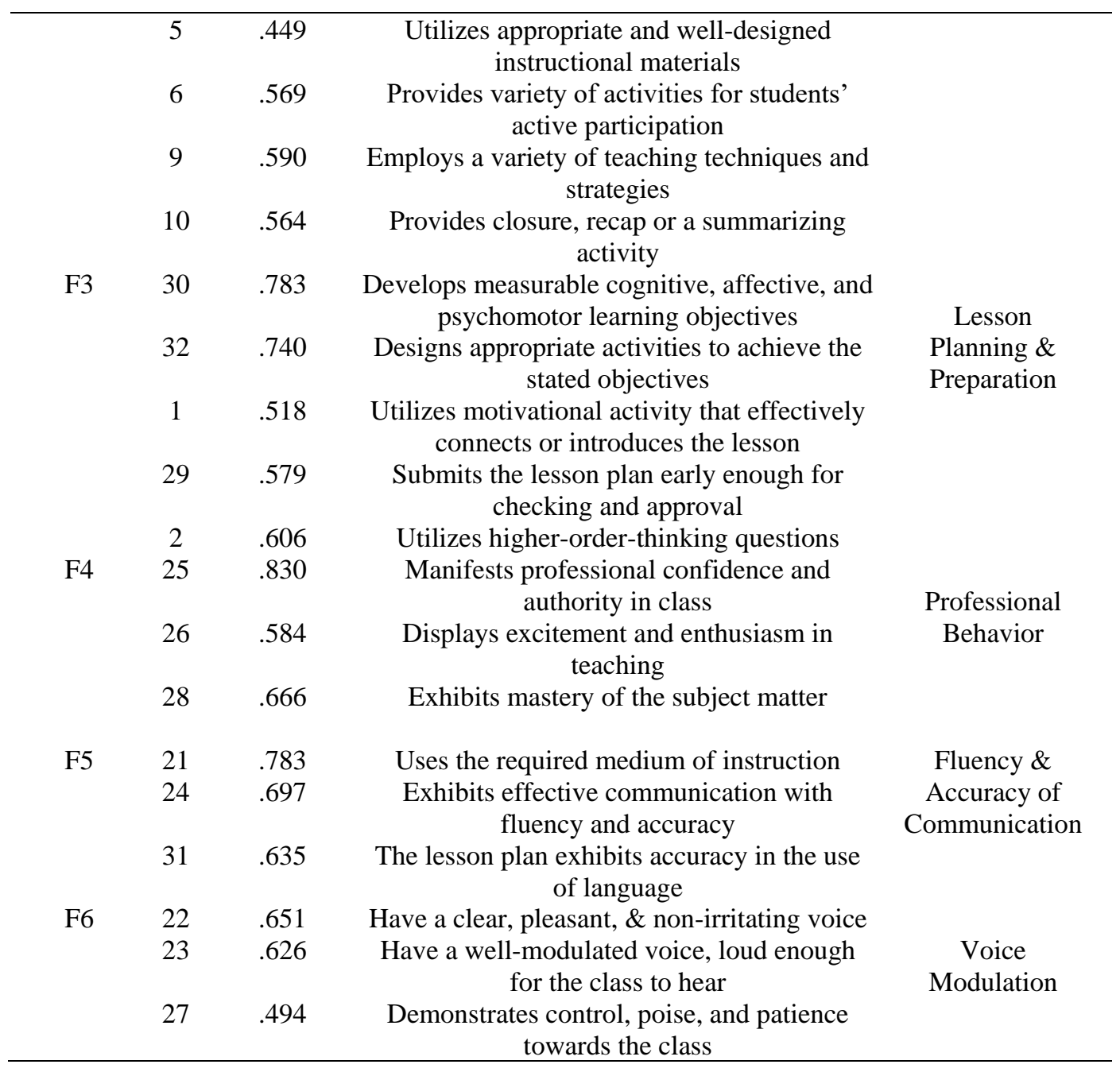

Factor 1: Classroom Management

The rotated matrix reveals that the respondents perceived this factor to be the most important construct with the highest explained variance of $15.801 \%$. Nine of the thirty-two variables load on significantly to this factor. The author labels this factor as "classroom management". Item number 14 (Sets the mood or atmosphere of the class for the lesson), which got the highest factor loading of .788 , accurately sums up the descriptions of the other variables loaded on this factor. Items number 16 and 15 which both got very high factor loading of .738 and .732 , respectively, support the naming of this factor as classroom management.

Exhibiting orderliness or being organized in conducting class activities, maintaining order and discipline, and utilizing strategies to reinforce positive behavior in the classroom are all hallmarks of good classroom 
management. Therefore, these are all very important factors in managing a class, as concluded by Marzano (2003) who stated that in a poorly managed class, effective teaching and learning cannot take place. He added that chaos will become the norm in the classroom if there are no clear rules, and procedures to follow that will guide decorum and good behavior. In contrast, he added that teaching and learning can only happen in a well-managed classroom and this doesn't just appear out of nowhere. The one who should have control over almost everything that happens in class - the teacher - must deliberately create it.

It is, therefore, imperative that every teacher training institutions should exhaust all means to help equip every education student with at least good classroom management skills before they handle classes in their student teaching internship (Su \& Pogoy, 2014).

\section{Factor 2: Teaching Strategy}

The respondents perceived this factor to be the second most important construct with the second highest explained variance of $13.286 \%$. Eight of the thirty-two variables load on significantly to this factor. The author identifies this factor as "teaching strategy" as all of the eight items loaded on this factor talk about this construct, which pertains to the teaching strategies employed by the teacher.

Items number 7 and 8, in Table 5, which got the highest factor loadings of .736 and .730 respectively, speak well of this factor. To be able to relate the lesson to students' real-life situations, the teacher should utilize a wellthought-of strategy such as grouping and cooperative learning. Employing variety of teaching techniques and strategies (Item \#9), providing variety of activities for students' active participation (Item \#6), and opportunities for application of the lesson (Item \#4) are all very important factors that contribute to the success of a teaching demonstration. In addition to these, the ones who have greatly benefited from a well-delivered lesson are not just the teachers themselves but the students above all. It has been proven and supported by various literature and studies such as that of Jalbani (2015) that effective teaching strategies have a great impact on students' academic performance and learning outcome.

\section{Factor 3: Lesson Planning and Preparation}

Five variables load on this factor with an explained variance of $10.967 \%$. The researcher labels this factor as "lesson planning and preparation" which explains the importance of every student teacher to prepare thoroughly for a teaching demonstration. Item number 30 having the highest factor loading of .783 emphasizes that the development of measurable cognitive, affective, and psychomotor learning objectives is very important as 
this serves as the guide of the student teacher as to what to do (strategies) in order to attain them (objectives). Both Item 32 (Designs appropriate activities to achieve the stated objectives) and Item 29 (Submits the lesson plan early enough for checking and approval) clearly show that this construct is apt to be called lesson planning and preparation. Although what will be observed in actual teaching is the implementation of what has already been planned, thorough planning and preparation largely contribute the success of the demonstration. A good lesson plan serves as a guide for the teacher on the specific steps to follow in carrying out the lesson. This would make it such that what was planned will be implemented and deviation from it will be prevented.

Hence, it is very important for student teachers to be well equipped with the necessary lesson planning skills as the success of their teaching demonstration largely hinges on a well-thought-of plan (Farrell, 2002; Shen et al., 2007).

\section{Factor 4: Professional Behaviour}

The rotated matrix reveals that the respondents perceived this factor to be as important as the first three factors, with three variables loaded with an explained variance of $10.532 \%$. Item 25 (manifests professional confidence and authority in class) have the highest loading of .830 . This item somehow summarizes the idea of the other two items, which also relate well and contribute to the same construct. Displaying excitement and enthusiasm in teaching (Item 26) and exhibiting mastery of the subject matter (Item 28) are indeed very important factors affecting the success of a teaching demonstration. These factors are somehow related to having good classroom management as the teacher's projection of control and confidence commands respect among the students. This projection of authority is very important then as this aspect helps bring a desirable change of behavior on the part of the students. Teachers must try to strike a good balance between that of a respected adult in class and someone who understands and stays relevant to the students. Thus, being a professional, a teacher is expected to treat every student with respect and care (Sherpa, 2018). This characteristic makes teachers the source of motivation and inspiration among their learners that according to Adams (2008) influences the life of the students and even beyond. Hence, possessing professional behavioural is an indispensable quality that each student teacher must strive hard to attain.

Factor 5: Accuracy \& Fluency of Communication

Three variables load on this factor with an explained variance of $9.318 \%$. This factor is labeled "communication skills" which emphasizes the importance of every student teacher to possess good communication skills. All 
three items relate well with each other and contribute to producing this construct.

Item number 21 has the highest factor loading of .783. It states that the use of the required medium of instruction is important. In addition, the teacher must exhibit fluency and accuracy in its usage (Item 24). Item 31 talks about lesson planning, which should also be in Factor 3. However, it states that the lesson plan exhibits accuracy in the use of language, which relates very well to this factor or dimension on communication skills. The teachers' being accurate and fluent especially in the use of the medium of instruction is also very important as this serves as the vehicle through which the lesson or content and the entire teaching-learning process are being delivered. Without it, delivery of instruction will be greatly affected.

Hence, it is very important that student teachers should acquire good communication skills (Khan, Khan, Zia-Ul-Islam, \& Khan, 2017). The entire educational levels from the basic to higher education must always make sure students constantly hone their communication skills if they were to compete and survive in the $21^{\text {st }}$-century world.

\section{Factor 6: Voice Modulation}

Three items load on this factor with an explained variance of $6.213 \%$. If five factors will be chosen in the extraction of factors, Item 22 and 23 will load together under Factor 5 Communication Skills, and Item 27 under Factor 1 Classroom Management. This loading only illustrates the limitation of this study, which has an explained variance of $66.117 \%$ and was conducted with 265 respondents. Increasing the number of respondents could potentially increase the variance and items or indicators will load together under the most appropriate factor.

Meanwhile, based on the fact that Item 22 and 23 have very high factor loadings, this result have sufficiently prove that this dimension or factor should be all about voice modulation. While it is important to speak fluently and accurately (Factor 5), the teacher should be able to speak loud enough for the students to hear.

There are also teachers who can modulate their voice well but lack fluency and accuracy, thereby not achieving effective communication. Hence, both of these factors are important for a successful teaching demonstration. Therefore, every teacher-training institution must also go the distance in making sure that every teacher candidate learns to modulate his or her voice, "an important educational resource" (Servilha, 2015, p. 13).

\section{Optimize Scale Length}

As suggested by both DeVellis (2017) and Hair, Black, Babin, Anderson and Tatham (2010), optimization of the scale can be done through 
subsequent reliability and validation test. Hence, further scale development and validation of the tool will soon be conducted by the researchers.

Teaching Demonstration Tool for Student Teachers

Hence, as the goal of this study, a tool designed to measure the teaching demonstration performance of pre-service student teachers is developed (See Appendix B). It is composed of thirty-two indicators grouped into six based on the six factors or constructs extracted through principal component analysis. The variances explained for each of the factors serve as the basis for the weight given in terms of percentage for each of the constructs. $30 \%$ is given for classroom management, $25 \%$ for teaching strategy, $15 \%$ for lesson planning and preparation, $15 \%$ for professional behavior, $10 \%$ for the accuracy and fluency of communication, and $5 \%$ for voice modulation.

\section{Conclusion}

This study develops an instrument that measures the teaching demonstration, or one-time performance of student teachers. The tool consists of indicators affecting the teaching demonstration performance of student teachers. These factors or indicators include classroom management, teaching strategy, lesson planning and preparation, professional behavior, accuracy and fluency of communication, and voice modulation. Of all these factors, classroom management has the greatest effect on the effectiveness of a teaching demonstration. It is therefore very important for student teachers to acquire good classroom management skills as the achievement of a successful teaching demonstration hinges on a well-organized and orderly class.

\section{References:}

1. Adams, H. (2008). The Education of Henry Adams. (Google Books version).

2. Aktag, I. (2003). Teacher efficacy of pre -service teachers in abant izzet baysal university in turkey (Order No. 3116556). Available from ProQuest Dissertations \& Theses Global. (305311169). Retrieved from

https://search.proquest.com/docview/305311169?accountid=173015

3. Al Barwani, T. A., Thabit Al-Ani, W., \& Hussein Amzat, I. (2012). An effective teaching model for public school teachers in the Sultanate of Oman: Students' stance. Education, Business and Society: Contemporary Middle Eastern Issues, 5(1), 23-46.manifests poise and patience towards the class

4. Alrefaei, N. (2015). Teachers' sense of efficacy: Examining the relationship of teacher efficacy and student achievement (Order No. 3704548). Available from ProQuest Central; ProQuest Dissertations \& 
Theses Global. (1690497495). Retrieved from https://search.proquest.com/docview/1690497495?accountid=173015

5. Alvis, J. D. (2009). Pre-service teaching experiences during the university of north carolina at greensboro summer music camp (Order No. 3355962). Available from ProQuest Dissertations \& Theses Global. (304963952). Retrieved from https://search.proquest.com/docview/304963952?accountid=173015

6. Anwer, M., Shen, H., Alwi, S. K., Raza, D., \& Nisa. (2017). Factors of effective mentoring: An empirical study of post-graduate faculty and students in pakistan. New Horizons, 11(1), 41-58. Retrieved from https://search.proquest.com/docview/1881103073?accountid=173015

7. Audet, K. K. (2014). Assessing pre-service teacher beliefs: Development of the effective teacher efficacy survey (Order No. 3684507). Available from ProQuest Central; ProQuest Dissertations \& Theses Global. (1660200232). Retrieved from https://search.proquest.com/docview/1660200232?accountid=173015

8. Bartlett, M. S. (1950). Tests of significance in factor analysis. British Journal of statistical psychology, 3(2), 77-85.

9. Bowman, M. L. (1984). The Development of the Audit of Principal Effectiveness. Unpublished doctoral dissertation, University of Missouri, Columbia.

10. Boyac, S. D., Küçükyilmaz, E. A., \& Genç-Ersoy, B. (2016). Future of classroom teaching according to the pre service classroom teachers. Journal of Education and Future, (9), 1-30. Retrieved from https://search.proquest.com/docview/1786778193?accountid=173015

11. Caster, K. A. (2018). Pre-service teachers feel ready, set, go on day one? comparing pre-service teachers teaching efficacy from a center of excellence teacher preparation model and a traditional model (Order No. 10827539). Available from ProQuest Dissertations \& Theses Global. (2120952201). Retrieved from https://search.proquest.com/docview/2120952201?accountid=173015

12. Cronbach, L. J. (1951). Coefficient alpha and the internal structure of tests. psychometrika, 16(3), 297-334.

13. Cil, O. (2014). Teacher identities as decision-makers and facilitators: An investigation of pre-service teacher performances and reflections within a clinical simulation (Order No. 3620447). Available from ProQuest Dissertations \& Theses Global. (1538111563). Retrieved from

https://search.proquest.com/docview/1538111563?accountid=173015

14. Cruz, A. (2002). Teaching behaviours of primary physical education student teachers (Order No. U169378). Available from ProQuest 
Dissertations \& Theses Global. (301563163). Retrieved from https://search.proquest.com/docview/301563163?accountid=173015

15. DeVellis, R. F. (2016). Scale development: Theory and applications (Vol. 26). Sage publications.

16. Farrell, T. S. (2002). Lesson planning. Methodology in language teaching: An anthology of current practice, 30-39.

17. Fox, W. \& Bayat, M.S. (2007) “A Guide to Managing Research" Juta Publications p.45

18. Gholam, A. P., \& Kobeissi, A. H. (2012). Teacher evaluation instruments/systems in lebanon and other major arab countries in comparison to evidenced-based characteristics of effective teacher evaluation instruments (Order No. 3544952). Available from ProQuest Central; ProQuest Dissertations \& Theses Global. (1237254782). Retrieved from https://search.proquest.com/docview/1237254782?accountid=173015

19. Gorsuch, R. L. (1983). Factor Analysis (2nd ed ). Hillsdale, New Jersey: Lawrence Erlbaum Associates.

20. Hatcher, R. M. (2008). Measurement of philosophical beliefs and self -efficacy of pre -service teachers (Order No. 3328197). Available from ProQuest Dissertations \& Theses Global. (304569125). Retrieved from https://search.proquest.com/docview/304569125?accountid=173015

21. Hrncir, S. M. (2007). The pre -service teacher /cooperating teacher relationship and its impact on pre -service teacher efficacy perceptions (Order No. 3268837). Available from ProQuest Dissertations \& Theses Global. (304840737). Retrieved from https://search.proquest.com/docview/304840737?accountid=173015

22. Ingle, K. M. (2017). A predictive study of pre-service teachers and success in final student internship (Order No. 10607342). Available from ProQuest Dissertations \& Theses Global. (1946189039). Retrieved from https://search.proquest.com/docview/1946189039?accountid=173015

23. Jalbani, L. N. (2015). The impact of effective teaching strategies on the students' academic performance and learning outcome: A literature review. GRIN Verlag.

24. Joliffe, I. T., \& Morgan, B. J. T. (1992). Principal component analysis and exploratory factor analysis. Statistical methods in medical research, 1(1), 69-95.

25. Kaiser, H. F. (1960). The application of electronic computers to factor analysis. Educational and psychological measurement, 20(1), 141151. 
26. Kaiser, H.F. (1970). A second-generation little jiffy. Psychometrica, 35, 401-415.

27. Khan, A., Khan, S., Zia-Ul-Islam, S., \& Khan, M. (2017). Communication Skills of a Teacher and Its Role in the Development of the Students' Academic Success. Journal of Education and Practice, 8(1), 18-21.

28. KOÇ, E. M. (2011). Factors affecting student teachers' perceptions on mentor roles: A study at distance english language teacher training program. TOJET : The Turkish Online Journal of Educational Technology, 10(1) Retrieved from https://search.proquest.com/docview/1288352063? accountid=173015

29. Lockwood, K. D. (2001). Evaluation of elementary student teachers' and their methods instructors' responses at four local universities (Order No. 3061756). Available from ProQuest Dissertations \& Theses Global. (304767443). Retrieved from https://search.proquest.com/docview/304767443 ?accountid=173015,

30. Marzano, R. J., Marzano, J. S., \& Pickering, D. (2003). Classroom management that works: Research-based strategies for every teacher. ASCD.

31. Meng, L., \& Muñoz, M. (2016). Teachers' perceptions of effective teaching: A comparative study of elementary school teachers from china and the USA.Educational Assessment, Evaluation and Accountability, 28(2), 179-199. doi:http://dx.doi.org/10.1007/s11092015-9230-9

32. Miller, L. R. (2001). Factors related to the performance of student teachers during special education placements (Order No. 3002978). Available from ProQuest Dissertations \& Theses Global. (250729930). Retrieved from https://search.proquest.com/docview/250729930?accountid=173015

33. Morris, A. K. (2007). Factors affecting pre-service teachers' evaluations of the validity of students' mathematical arguments in classroom contexts. Cognition and Instruction, 25(4), 479-522. doi:http://dx.doi.org/10.1080/0737000070163240,

34. Nordyke, A. M. (2011). Models of teaching: Indicators influencing teachers' perception of pedagogical choice (Order No. 3477977). Available from ProQuest Central; ProQuest Dissertations \& Theses Global. (901460600). Retrieved from https://search.proquest.com/docview/901460600? accountid=173015

35. Patton, L. S. (2002). A study of mathematics anxiety of the pre-service elementary teacher at the university of arizona (Order No. 3050336). Available from ProQuest Dissertations \& Theses Global. 
(304802152).

Retrieved

from

https://search.proquest.com/docview/304802152?accountid=173015

36. Pearson, K. (1901). LIII. On lines and planes of closest fit to systems of points in space. The London, Edinburgh, and Dublin Philosophical Magazine and Journal of Science, 2(11), 559-572.

37. Perkmen, S. (2008). Factors that influence pre -service teachers' technology integration performance (Order No. 3310804). Available from ProQuest Central; ProQuest Dissertations \& Theses Global. (304612130). Retrieved from https://search.proquest.com/docview/304612130?accountid=173015

38. Perry, R. K. (2016). Influences of co-teaching in student teaching on pre-service teachers' teacher efficacy (Order No. 10105248). Available from ProQuest Central; ProQuest Dissertations \& Theses Global. (1790115590). Retrieved from https://search.proquest.com/docview/1790115590?accountid=173015

39. Popham, W. J. (1990). Modem educational measurement: A practitioner's perspective (2nd ed ). Englewood Cliffs, NJ: Prentice Hall.

40. Rachal, J. C. (1981). Student Teacher Effectiveness In The Summative Self-evaluation Of Teaching Competencies (Order No. 8117644). Available from ProQuest Dissertations \& Theses Global. (303021869). Retrieved from https://search.proquest.com/docview/303021869?accountid=173015

41. Schilling, J. W. (1997). Elements of effective teaching: Testing their values with ohio middle school principals in the 1990s (Order No. 9813636). Available from ProQuest Dissertations \& Theses Global. (304336382).

Retrieved

from https://search.proquest.com/docview/304336382?accountid=173015

42. Servilha, E. A. M., \& Costa, A. T. F. D. (2015). Knowledge about voice and the importance of voice as an educational resource in the perspective of university professors. Revista CEFAC, 17(1), 13-26.

43. Shen, J., Poppink, S., Cui, Y., \& Fan, G. (2007). Lesson planning: A practice of professional responsibility and development. Educational horizons, 85(4), 248-258.

44. Sherpa, K. (2018). Importance of professional ethics for teachers. International Education and Research Journal, ierj.in/journal/index.php/ierj/article/view/1602.

45. Su, S. C., \& Pogoy, A. M. (2014). Classroom Practices of Teacher Interns in Taiwan and Philippines: A Comparative Study. Recoletos Multidisciplinary Research Journal, 2(2). 
46. Taherdoost, H. A. M. E. D., Sahibuddin, S. H. A. M. S. U. L., \& Jalaliyoon, N. E. D. A. (2014). Exploratory factor analysis; concepts and theory. Advances in Applied and Pure Mathematics, 375382.

47. Taylor, K. R. (2010). The development of an instrument to measure teacher education candidates' dispositions (Order No. 3426685). Available from ProQuest Central; ProQuest Dissertations \& Theses Global. (763403465). Retrieved from https://search.proquest.com/docview/763403465 accountid=173015

48. Walker, A. A. (2014). The perceived impact of pre-service student teachers on the optimal learning environment of the students they teach and the teachers who mentor them (Order No. 3680770). Available from ProQuest Dissertations \& Theses Global. (1654778735). Retrieved from https://search.proquest.com/docview/1654778735? accountid=173015

49. Wang, L. (2010). Perception, implementation and mentoring: A constructivist approach to pre-service physical education teachers (Order No. 3489025). Available from ProQuest Central; ProQuest Dissertations \& Theses Global. (912746454). Retrieved from

https://search.proquest.com/docview/912746454 accountid=173015

50. Williams, R. E. (2010). Administrator and teacher perceptions of the qualities of effective teachers (Order No. 3438556). Available from ProQuest Dissertations \& Theses Global. (847258578). Retrieved from

https://search.proquest.com/docview/847258578?accountid=173015

51. Winters, B. K. (2010). An investigation of pre-service teachers' perceptions of personal and general teaching efficacy prior to and following student teaching (Order No. 3464552). Available from ProQuest Central; ProQuest Dissertations \& Theses Global. (881648031). Retrieved from https://search.proquest.com/docview/881648031 accountid=173015

52. Yong, A. G., \& Pearce, S. (2013). A beginner's guide to factor analysis: Focusing on exploratory factor analysis. Tutorials in quantitative methods for psychology, 9(2), 79-94.

53. Yu, J. H. (2013). Development and validation of pre-service teachers' personal epistemologies of teaching scale (PT-PETS) (Order No. 3613545). Available from ProQuest Central; ProQuest Dissertations \& Theses Global. (1512222013). Retrieved from https://search.proquest.com/docview/1512222013?accountid=173015 


\section{APPENDIX A}

Teaching Performance Indicators Gathered from the Given Literature

A. Al Barwani, T. A., Thabit Al-Ani, W., \& Hussein Amzat, I. (2012)

- Manifests intelligence and wits

- Manifests fairness and good judgment

- Exudes pleasing personality

- Promotes positive discipline, non-negative reinforcements

- Utilizes various classroom activities

- Good time management skills

- Uses suitable evaluation strategies

- Can control the factors that interrupt or delay the lesson.

- Gives the student enough time to answer question.

B. Meng, L., and Muñoz, M. (2016)

- Maintains a physically and emotionally safe environment for students

- Reinforces expectations for positive behavior and responds to misbehaviors promptly

- Limits interruptions and focuses classroom time on teaching and learning

- Establishes and communicates high expectations for student achievement

- Aligns evaluation/assessment to lesson objectives

- Links instruction to students' real-life

- Employs a variety of techniques and instructional strategies

- Designs lessons to actively engage the students

- Uses a variety of questioning techniques

- Provides clear examples and offers guided practice

- Uses effective grouping strategies

C. Schilling, J. W. (1997)

- Allows "wait time" for student interaction.

- Encourages students to talk without interrupting them.

- Shows enthusiasm for teaching and learning

- Connects opening activity to main lesson

- Uses deserved praise sparingly.

- Let students know about the correctness of the response

- Keeps students actively participating in the lesson

- Summarizes/reviews material covered to develop a sense of completeness or mastery

D. Anwer, M., Hong, S. H. E. N., Alwi, S., and Raza, D. (2017)

- Utilizes strategies that reinforce positive behaviour and prevents negative ones

- Utilizes Instructional/academic games

- Provides Closure or a summarizing activity

- Let the students know the objectives of the class

- Utilizes motivational activity that effectively connects/introduce the lesson 
- Uses variety of activities

E. Williams, R. E. (2010)

- Links instruction to students' real-life situations

- Links instruction to objectives

- Maintains order and routines

- Prepares materials ahead of time and have them ready to use

- Maintains a physically and emotionally safe environment for students

- Reinforces expectations for positive behavior and responds to misbehaviors promptly

- Employs a variety of techniques and instructional strategies to accomplish learning goals

- Designs lessons to actively engage students in the learning process

- Uses a variety of questioning techniques

- Provides clear examples and offers guided practice

- Uses effective grouping strategies

- Uses homework to augment student learning

F. Taylor, K. R. (2010)

- Demonstrates enthusiasm when teaching the subject matter

- Models effective communication strategies when interacting with students.

- Designs assessments/tests to reflect the lesson objectives

G. Gholam, A. P. and Kobeissi, A. H. (2012)

- Taps students' prior knowledge

- Utilizes a way to communicate learning objectives to students

- Uses a variety of instructional strategies

- Engages students in active learning

- Aligns and integrates instruction and assessment 


\section{APPENDIX B \\ Teaching Demonstration Tool for Student Teachers}

\section{Teaching Demonstration Tool for Student Teachers}

Name of Student Teacher:

Date of Teaching: Grade \& Subject:

Directions: Rate the Student Teacher using the following scale: 10 - Excellent 8 -Very Satisfactory 6 -Satisfactory 4 -Moderately Satisfactory 2 -Poor
A. LESSON PLANNING $-\mathbf{1 5 \%}$

1. Develops measurable cognitive, affective, and psychomotor learning objectives

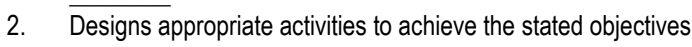

3. Exhibits accuracy in the use of language

4. Submits the lesson plan early enough for checking and approval

B. CLASSROOM MANAGEMENT - 30\%

Total $=$ $14 \times 0.15=$

1. Sets the mood or atmosphere of the class for the lesson

2. Exhibits orderliness or being organized in conducting class activities

3. Maintains order and discipline

4. Utilizes strategies to reinforce positive behavior and prevent the negative ones

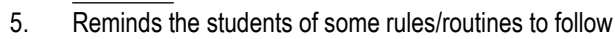

6. Limits interruptions and focusing classroom time on teaching and learning

7. Demonstrates control, poise, and patience towards the class

Total $=$ 6.

C. TEACHING STRATEGY $-25 \%$

7.

1. Uses effective grouping and cooperative learning strategies

2. Relates the lesson to students' real-life situations

3. Utilizes motivational activity that effectively connects or introduces the lesson

2.

4. Utilizes higher-order-thinking questions

5. Taps or activates the prior knowledge of students

6. Provides opportunities for follow up or application of the lesson

7. Utilizes appropriate and well-designed instructional materials

8. Provides variety of activities for students' active participation

9. Provides closure, recap or a summarizing activity

10. Utilizes higher order thinking questions in Assessment tasks

11. $\overline{\text { Observes }}$ or follows the principles of test construction \& administration

12. Designs assessment procedures that are aligned with the stated objectives

D. PROFESSIONAL BEHAVIOR $-15 \%$

Total $=$ $/ 12 \times 0.25=$

1. Manifests professional confidence and authority in class 